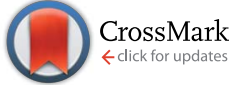

Cite this: RSC Adv., 2015, 5, 48468

\title{
Combination of ultrasound and Fenton treatment for improving the hydrolysis and acidification of waste activated sludge
}

\author{
Hongxu Bao, ${ }^{* a b}$ Lei Jiang, ${ }^{a}$ Chunxiao Chen, ${ }^{a}$ Chunxue Yang, ${ }^{b}$ Zhangwei He, \\ Yaodong Feng, ${ }^{a}$ Weiwei Cai, ${ }^{b}$ Wenzong Liu ${ }^{\text {bc }}$ and Aijie Wang*bc
}

The effects of ultrasound (US), Fenton treatment, and combined US/Fenton treatment as physicochemical pretreatment processes for waste activated sludge (WAS) hydrolysis and acidification were investigated in this study. The soluble carbohydrate concentrations after US/Fenton treatment were 2.36-fold, 2.17-fold and 17.11-fold more than that obtained by the Fenton treatment, US and control tests, respectively. The corresponding concentrations of soluble protein after US/Fenton treatment were 2.43-fold, 1.47-fold and 13.37 -fold more than that obtained by the Fenton treatment, US and control tests, respectively. The degree of sludge disintegration ( $\left(\mathrm{DD}_{\mathrm{COD}}\right.$ ) for the US/Fenton treatment was $15.4 \%$, whereas it was only $9.97 \%$ and $3.18 \%$ for the US and Fenton tests. The maximum accumulation of volatile fatty acids (VFAs) was obtained by the US/Fenton pretreatment ( $4594 \mathrm{mg} \mathrm{COD} \mathrm{L}^{-1}$ ), which presented obvious advantages over US (3485 mg COD L $\mathrm{mg}^{-1}$ ) and Fenton (2700 $\mathrm{mg} \mathrm{COD} \mathrm{L}^{-1}$ ) treatments. The combination of the US and Fenton treatments had a synergetic effect on improving the hydrolysis and subsequent acidification of WAS.

Received 1st April 2015

Accepted 18th May 2015

DOI: 10.1039/c5ra05791d

www.rsc.org/advances improve anaerobic fermentation efficiency for VFAs accumulation.

Ultrasound (US) is an effective mechanical pretreatment method for enhancing the biodegradability of sludge, and Pilli et al. reported that US would be very effective for sludge disposal and treatment in all WWTPs. ${ }^{11}$ US can be applied to disrupt sludge flocs and microbial cell walls, which could disintegrate sludge and release organic substances into the liquid phase. Hydro-mechanical shear forces are predominantly responsible for WAS disintegration, and the oxidizing effect of ${ }^{\circ} \mathrm{OH}$ can contribute to WAS disintegration when ultrasonic intensity increases to a certain extent. ${ }^{\mathbf{1 2}}$ High specific energy input (>5000 kJ kg $\mathrm{TS}^{-1}$ ), high power density/intensity and long sonication time were found suitable for sludge disintegration. ${ }^{\mathbf{1 3}}$

Fenton reaction, an environmentally friendly technique, is one of the most effective advanced oxidation processes. In the Fenton reaction process, ferrous iron $\left(\mathrm{Fe}^{2+}\right)$ catalyzes the decomposition of $\mathrm{H}_{2} \mathrm{O}_{2}$. This can accelerate the generation of hydroxyl radicals, which are powerful and non-selective oxidizing agents. ${ }^{14}$ Hydroxyl radicals can pass easily through the microbial cell membrane to discharge intracellular organic substances into the liquid phase. Meanwhile, the hydroxyl radicals can oxidize the recalcitrant compounds into biodegradable ones, which can serve as nutrients for further biological treatment. ${ }^{15}$

Some researchers have studied the combination of US and Fenton processes for sludge treatment. ${ }^{16,17}$ Qiu et al. (2013) investigated ultrasonic irradiation as a pretreatment for Fentonacclimation treatment to enhance the efficiency of sludge 
reduction. ${ }^{16}$ Ning et al. (2014) studied the effect of US-assisted Fenton (US/Fenton) treatment on the physicochemical properties of textile dyeing sludge. ${ }^{17}$ However, little work has explored the effects of combined treatments on the hydrolysis and further acidification processes of WAS. US can enhance the oxidation rate of the Fenton process by generating more ${ }^{\circ} \mathrm{OH}$ because of the cavitation within US irradiation. ${ }^{17}$ Thus, the US/Fenton treatment may have a synergetic effect on WAS pretreatment. The aim of the present work is to investigate the influence of US, Fenton and US/Fenton pretreatment on WAS hydrolysis and further acidification processes during anaerobic fermentation.

\section{Material and methods}

\subsection{Sludge properties}

WAS was collected from the secondary sedimentation tank of the Taiping WWTP (Harbin City, Heilongjiang Province, China). The sludge was firstly concentrated by gravity settling for $24 \mathrm{~h}$ at $4{ }^{\circ} \mathrm{C}$ and then filtered through $1.0 \mathrm{~mm}$ sieves to eliminate the larger fraction and provide homogeneous digested sludge. The filtered WAS was stored at $4{ }^{\circ} \mathrm{C}$ for later use. WAS should be diluted before using, and its main characteristics are listed in Table 1 .

\subsection{Pretreatment methods}

US treatment was performed in an US reactor at a frequency of $40 \mathrm{kHz}$ (KQ2200DA, Kunshan Shumei Inc., China). The US power density $(\mathrm{P})$ was adjusted to $0.4 \mathrm{~kW} \mathrm{~L}^{-1}$, and the treatment time $(t)$ was $10 \mathrm{~min}$. Fenton treatment was conducted with a magnetic stirrer (JB-2A, Shanghai Leici Inc., China). Sludge samples were initially adjusted to $\mathrm{pH} 3$ by sulfuric acid $\left(\mathrm{H}_{2} \mathrm{SO}_{4}\right)$, and the concentration of $\mathrm{Fe}^{2+}$ was adjusted to $0.04 \mathrm{~g} \mathrm{~L} \mathrm{~L}^{-1}$ by adding ferrous sulfate $\left(\mathrm{FeSO}_{4} \cdot 7 \mathrm{H}_{2} \mathrm{O}\right)$. The reaction was then initiated $90 \mathrm{~min}$ after adding $10 \mathrm{~g} \mathrm{~L}{ }^{-1} \mathrm{H}_{2} \mathrm{O}_{2}$ $(30 \mathrm{wt} \%){ }^{16}$

For US/Fenton treatment, sludge was first pretreated by the US method and then pretreated with Fenton reaction. The treatment conditions were the same as mentioned above. The soluble organic matter content and particle size were measured after each pretreatment process.

Table 1 Characteristics of waste activated sludge samples

\begin{tabular}{ll} 
Parameter & Average value $^{a}$ \\
\hline pH & $6.85 \pm 0.5$ \\
TSS (total suspended solids) & $24381 \pm 368$ \\
VSS (volatile suspended solids) & $15124 \pm 142$ \\
Soluble chemical oxygen demand & $213 \pm 7$ \\
Total chemical oxygen demand & $19333 \pm 225$ \\
Total SCFAs (as COD) & $21 \pm 2$ \\
Solute carbohydrate (as COD) & $25 \pm 3$ \\
Solute protein (as COD) & $154 \pm 13$
\end{tabular}

${ }^{a}$ All values are expressed in $\mathrm{mg} \mathrm{L}^{-1}$ except $\mathrm{pH}$.

\subsection{Batch-scale anaerobic fermentation}

Batch anaerobic fermentation of the control (untreated) and the US-, Fenton- and US/Fenton-pretreated samples (350 mL) were conducted in $500 \mathrm{~mL}$ serum bottles. Nitrogen gas was flushed for $10 \mathrm{~min}$ to remove oxygen from the system, and then all bottles were sealed with butyl rubber stoppers and stirred in an air-bath shaker (SHZ-82, Zhiborui Inc., China) at $35 \pm 1{ }^{\circ} \mathrm{C}$ and $100 \mathrm{rpm}$ for 16 day. The variations in carbohydrate, protein and VFA contents were measured. Simultaneously, biogas was collected using Cali-5-Bond ${ }^{\mathrm{TM}}$ gas-sampling bags $(1 \mathrm{~L})$. Batch tests were carried out in duplicate for each test.

\subsection{Analytical methods}

Supernatant was used to analyze soluble chemical oxygen demand (SCOD) along with carbohydrate, protein and VFA contents. Sludge samples were centrifuged at a speed of $10000 \mathrm{rpm}$ for $10 \mathrm{~min}$, and the supernatant was then filtered through a $0.45 \mu \mathrm{m}$ cellulose nitrate membrane filter. The supernatant was stored at $4{ }^{\circ} \mathrm{C}$ prior to analysis. Measurements of SCOD, total chemical oxygen demand (TCOD), total suspended solids (TSS) and volatile suspended solids (VSS) were conducted according to the standard methods. ${ }^{18}$ The $\mathrm{pH}$ value was measured with a $\mathrm{pH}$ meter (Seven Multi, Mettler Toledo, Switzerland). Carbohydrate content was measured by the phenol-sulfuric method with glucose as the standard. ${ }^{19}$ Soluble protein content was determined by the bicinchoninic acid method with bull serum albumin as the standard. ${ }^{20}$ VFAs were analyzed using gas chromatography (GC; Agilent 7890), and gas composition was determined by GC (Agilent 4890D). ${ }^{21}$

The degree of sludge disintegration $\left(\mathrm{DD}_{\mathrm{COD}}\right)$ was determined by measuring the variation in chemical oxygen demand (COD) according to eqn (1):

$$
\mathrm{DD}_{\mathrm{COD}}(\%)=\frac{\mathrm{SCOD}_{\mathrm{t}}-\mathrm{SCOD}_{0}}{\mathrm{TCOD}-\mathrm{SCOD}_{0}} \times 100
$$

where TCOD is the total COD of the untreated sludge, and $\mathrm{SCOD}_{\mathrm{t}}$ and $\mathrm{SCOD}_{0}$ are the soluble COD of the treated and untreated sludge samples, respectively.

In this study, VFA content was determined as the sum of acetic (HAc), propionic ( $\mathrm{HPr}), n$-butyric $(n-\mathrm{HBu})$, iso-butyric (iso-HBu), $n$-valeric ( $n$-HVa) and iso-valeric (iso-HVa) acids. The COD conversion factors were $1.06 \mathrm{~g}$ COD $/ \mathrm{g}$ carbohydrate (assumed as $\mathrm{C}_{6} \mathrm{H}_{12} \mathrm{O}_{6}$ ), $1.50 \mathrm{~g} \mathrm{COD} / \mathrm{g}$ protein (assumed as $\left.\left(\mathrm{C}_{4} \mathrm{H}_{6.1} \mathrm{O}_{1.2} \mathrm{~N}\right)_{x}\right), 1.07 \mathrm{~g} \mathrm{COD} / \mathrm{g} \mathrm{HAc}, 1.51 \mathrm{~g} \mathrm{COD} / \mathrm{g} \mathrm{HPr}, 1.82 \mathrm{~g}$ $\mathrm{COD} / \mathrm{g} \mathrm{HBu}$, and $2.04 \mathrm{~g} \mathrm{COD} / \mathrm{g} \mathrm{HVa} .{ }^{21}$

The particle size distributions of the sludge samples were determined by a Malvern particle size analyzer (MastersizerAPA2000, UK) with a measurement range from 0.02 to $2000 \mu \mathrm{m}$.

\section{Results and discussion}

\subsection{Effect of pretreatment on WAS disintegration}

Sludge contains large amounts of organic matter, mostly in the form of solid particles. WAS pretreatment can enhance the release of soluble organics, which can be evaluated by $\mathrm{DD}_{\mathrm{COD}}$, soluble carbohydrate and protein contents. As shown in Fig. 1, 


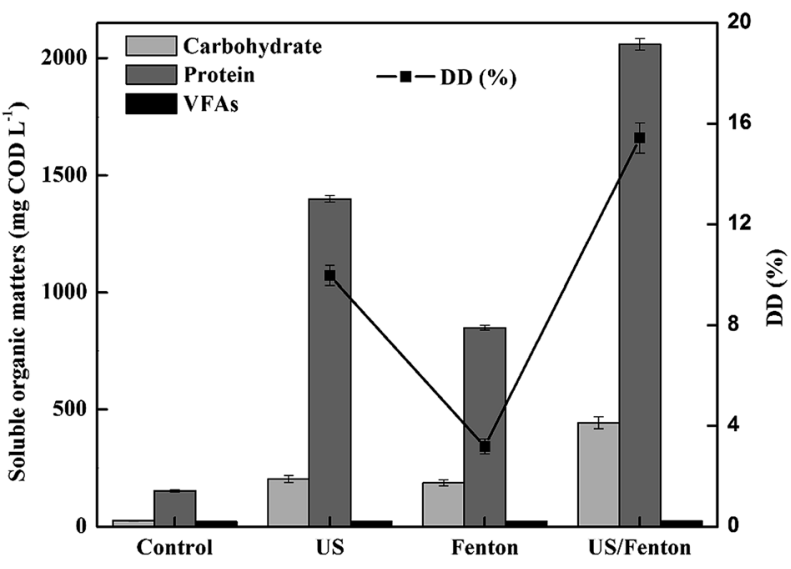

Fig. 1 WAS disintegration with different pretreatments.

$\mathrm{DD}_{\mathrm{COD}}$ was $9.97 \%, 3.18 \%$ and $15.4 \%$, after US, Fenton and US/Fenton pretreatments, respectively. Meanwhile, soluble carbohydrates and proteins increased with increasing $\mathrm{DD}_{\mathrm{COD}}$. The soluble carbohydrate concentration after US/Fenton treatment was $441 \mathrm{mg}$ COD L ${ }^{-1}$, which was 2.36-fold, 2.17-fold and 17.11-fold more than those obtained for the Fenton, US and control tests, respectively. The corresponding concentration of soluble protein after US/Fenton treatment was $2059 \mathrm{mg}$ COD $\mathrm{L}^{-1}$, which was 2.43-fold, 1.47-fold and 13.37-fold more than those obtained for the Fenton, US and control tests, respectively. These results are similar with those of previous studies and suggest that intracellular microbial organic matter in WAS can be effectively released into the extracellular environment by US/Fenton pretreatment. ${ }^{16}$ WAS disintegration occurred mainly as a result of hydro-mechanical shear forces produced by US cavitation bubbles, ${ }^{12}$ and longer treatment time or higher US intensity broke more microbial cell walls, releasing intracellular material into the liquid phase. ${ }^{4}$ Hydroxyl radicals produced by Fenton could also pass easily through the microbial cell membrane to discharge intracellular organic substances into

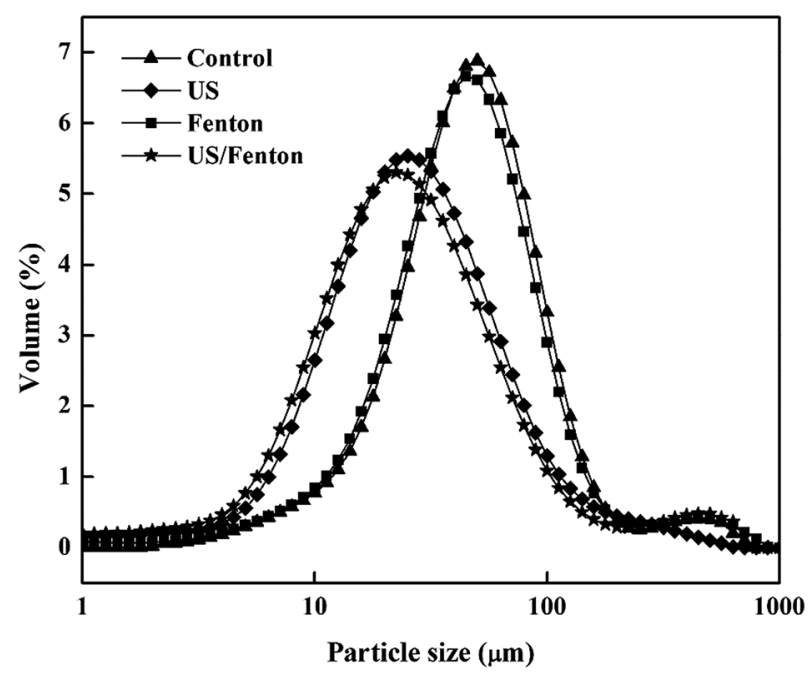

Fig. 2 Particles size distribution with different pretreatments. the liquid phase. ${ }^{15}$ The release of substantial components after sludge pretreatment is beneficial for the subsequent sludge anaerobic fermentation. No significant increases in VFAs concentration were observed in any of the samples.

Sludge disintegration was closely related to sludge particle size. The particle size distributions before and after treatment are shown in Fig. 2. For untreated WAS, the particle size profile presented a maximum representing the highest volume percentage $(6.88 \%)$ at $50.24 \mu \mathrm{m}$, while the other three peaks were centered at $25.18 \mu \mathrm{m}$ (5.54\%, US), $44.77 \mu \mathrm{m}$ (6.66\%, Fenton) and $22.44 \mu \mathrm{m}$ (5.3\%, US/Fenton). The d50 ( $\mu \mathrm{m})$, the value that $50 \%$ of the volumes distribute below, was $44.01 \mu \mathrm{m}$ for the untreated sludge; this was a little higher than the d50 for the Fenton-treated sludge $(41.53 \mu \mathrm{m})$ and much higher than those of the US-treated $(24.52 \mu \mathrm{m})$ and US/Fenton-treated $(22.63 \mu \mathrm{m})$ sludges. The smaller particle size indicated that US/Fenton pretreatment significantly disrupts sludge floc structure and converts organic matter into soluble phases. ${ }^{17}$

Shock waves generated by US could disrupt large particles, leading to an increase in the number of smaller particles. Thus, US resulted in a greater decrease in particle size. In contrast, Fenton oxidation resulted in insignificant effects on particle
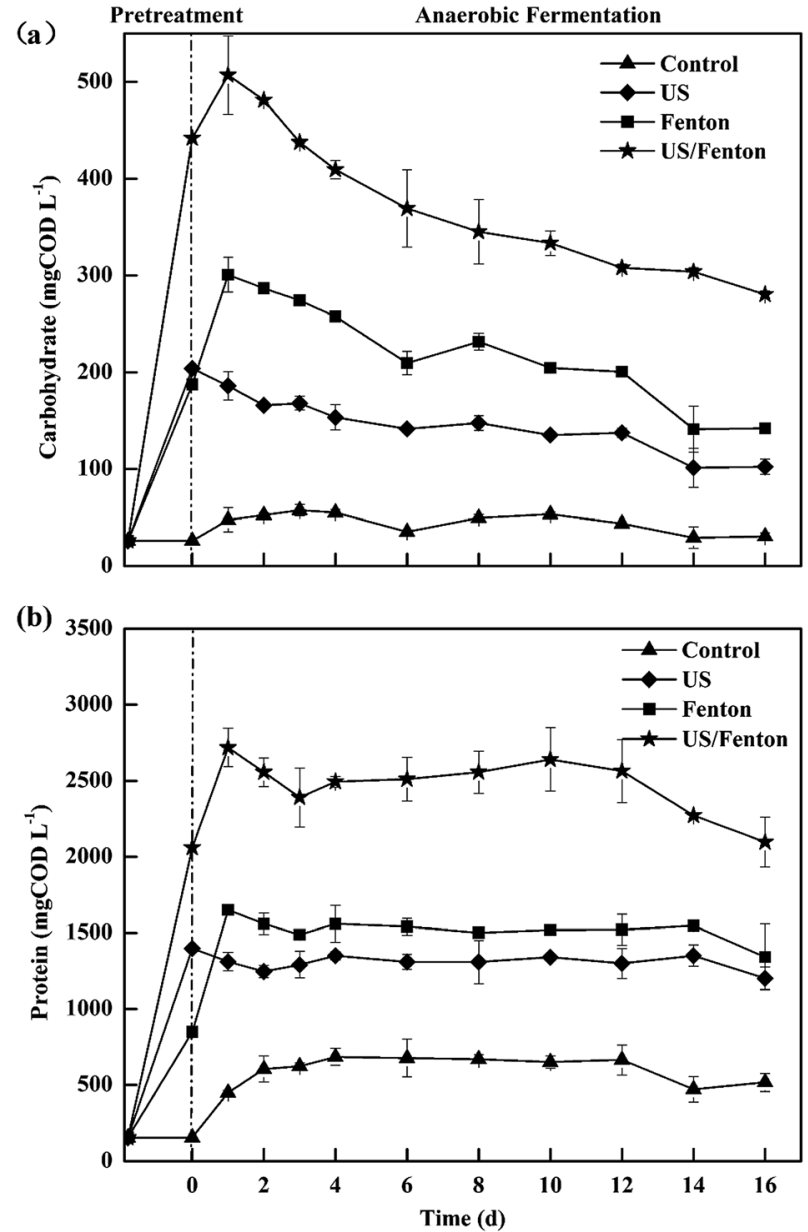

Fig. 3 Variation in soluble organic matter during anaerobic fermentation. 
size. This may be explained by the acidic $\mathrm{pH}$ and generation of ferric hydroxide and ferric hydroxo complexes. ${ }^{22}$

\subsection{Consumption of soluble organics}

Protein and carbohydrate accounted for almost $70-80 \%$ of the main constituents of WAS. ${ }^{11}$ Fig. 3 shows the changes in soluble carbohydrate and protein contents after different pretreatments with increasing anaerobic fermentation time. Soluble carbohydrate and protein concentrations in the pretreated sludge were higher than those in the untreated sludge, and both decreased with increasing fermentation time. In addition, the combined treatment presented obvious advantages for the release of organic matter compared to US and Fenton alone, while there was little variation for the untreated sludge.

The maximum concentrations of soluble carbohydrate were $507 \pm 40 \mathrm{mg} \mathrm{COD} \mathrm{L}^{-1}, 300 \pm 18 \mathrm{mg} \mathrm{COD} \mathrm{L}^{-1}$ and $204 \pm 5 \mathrm{mg}$ $\mathrm{COD} \mathrm{L}^{-1}$, respectively, for US/Fenton-treated sludge, Fentontreated sludge and US-treated sludge, respectively. Nevertheless, the soluble carbohydrate concentration was only $57 \pm 6 \mathrm{mg}$

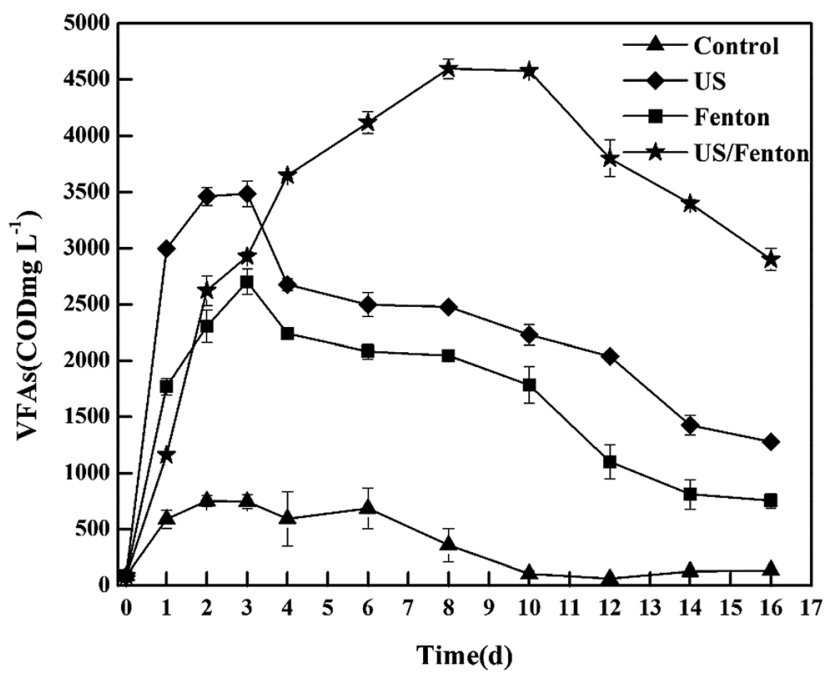

Fig. 4 Variation in total VFAs concentration during anaerobic fermentation.
$\mathrm{COD} \mathrm{L}^{-1}$ in the control (Fig. 3a). In contrast, the peak concentrations of soluble protein were $2719 \pm 127 \mathrm{mg} \mathrm{COD} \mathrm{L}^{-1}, 1650 \pm$ $28 \mathrm{mg} \mathrm{COD} \mathrm{L}^{-1}$ and $1399 \pm 10 \mathrm{mg} \mathrm{COD} \mathrm{L}^{-1}$ for US/Fenton-, Fenton-, and US-treated sludges, respectively, while it was only $684 \pm 56 \mathrm{mg} \mathrm{COD} \mathrm{L}^{-1}$ in the control (Fig. 3b). The change in protein concentration was stable after the third day because the release rate and degradation rate attained a balance; the protein concentration then decreased after the twelfth day because the degradation rate exceeded the release rate. ${ }^{23}$ The protein degradation rate was lower than the carbohydrate degradation rate, which may be due to the poor biodegradability of proteins compared to carbohydrates and lipids. ${ }^{24}$

\subsection{VAs production and composition}

More hydrolysis products provided more substrates for acidification, and more VFAs could be obtained. ${ }^{25}$ As shown in Fig. 4, during fermentation, the accumulated VFAs concentration increased during the first three days and then decreased in the US-treated, Fenton-treated and untreated sludge. However, in the US/Fenton-treated sludge, the concentration of accumulated VFAs increased during the first eight days and then decreased. Meanwhile, the VFAs concentrations in all the pretreated sludges were higher than that in untreated sludge. The highest VFAs production was $3485 \mathrm{mg} \mathrm{COD} \mathrm{L}{ }^{-1}$ and $2700 \mathrm{mg}$ $\mathrm{COD} \mathrm{L}^{-1}$ for the US and Fenton treatments on the third day, while it was $4594 \mathrm{mg} \mathrm{COD} \mathrm{L}^{-1}$ for the US/Fenton treatment on the eighth day. The time lag in VFAs production in the combined treatment test may be attributed to a lower acidogenic bacteria activity or lower biomass of acidogenic bacteria caused by the combined pretreatment; however, there was a remarkable increase in VFAs production when the acidogenic bacteria became enriched with increasing fermentation time.

The comparison of VFAs production under different pretreatments is presented in Table 2. As been presented, US combined Fenton pretreatment for VFAs production from WAS was first mentioned in this study. US combined with acid or alkaline treatment (nos 1, 2 and 3) enhanced VFAs accumulation compared with US alone, regardless of whether the $\mathrm{pH}$ was adjusted initially or throughout the entire fermentation time. ${ }^{26-28}$ Meanwhile, US combined with biological methods

Table 2 Comparison of VFAs production from WAS under different pretreatments combined with ultrasound

\begin{tabular}{|c|c|c|c|c|c|c|c|}
\hline No. & Pretreated method and pa & rameter & Fermentation $\mathrm{pH}$ & $\begin{array}{l}\text { Fermentation } \\
\text { time (day) }\end{array}$ & Temp. $\left({ }^{\circ} \mathrm{C}\right)$ & $\begin{array}{l}\text { Maximum VFAs } \\
\text { production }\end{array}$ & Reference \\
\hline 1 & Ultrasound-alkaline & $20 \mathrm{kHz}, 10 \min , 1.0 \mathrm{~kW} \mathrm{~L}^{-1}$ & 10 & 3 & $21 \pm 1$ & $3110 \mathrm{mg} \mathrm{COD} \mathrm{L}{ }^{-1}$ & 26 \\
\hline \multirow[t]{2}{*}{2} & Ultrasound-acid & $28 \mathrm{kHz}, 60 \mathrm{~min}, \mathrm{pH} 3$ & 6 & 10.5 & $35 \pm 2$ & $1700 \mathrm{mg} \mathrm{L}^{-1}$ & 27 \\
\hline & Ultrasound-alkaline & $28 \mathrm{kHz}, 60 \mathrm{~min} ; \mathrm{pH} 12$ & 6 & 10.5 & $35 \pm 2$ & $3700 \mathrm{mg} \mathrm{L}^{-1}$ & \\
\hline 3 & Ultrasound-alkaline & $\begin{array}{l}20 \mathrm{kHz}, 30 \mathrm{~min} \\
2.0 \mathrm{~kW} \mathrm{~L}^{-1} ; \mathrm{pH} 11\end{array}$ & Uncontrolled & 15 & $20 \pm 2$ & $1751 \mathrm{mg} \mathrm{L}^{-1}$ & 28 \\
\hline 4 & $\begin{array}{l}\text { Ultrasound-thermophilic } \\
\text { bacteria }\end{array}$ & $\begin{array}{l}40 \mathrm{kHz}, 0.5 \mathrm{~kW} \mathrm{~L}{ }^{-1}, \\
10 \mathrm{~min} ; 60{ }^{\circ} \mathrm{C}, 6 \mathrm{~h}, \\
10 \% \text { Geobacillus } \mathrm{sp} . \mathrm{G} 1\end{array}$ & Uncontrolled & 4 & 35 & $4437 \mathrm{mg} \mathrm{COD} \mathrm{L}{ }^{-1}$ & 29 \\
\hline 5 & Ultrasound-Fenton & $\begin{array}{l}40 \mathrm{kHz}, 0.4 \mathrm{~kW} \mathrm{~L}^{-1}, \\
10 \mathrm{~min} ; 0.04 \mathrm{~g} \mathrm{~L}^{-1} \mathrm{Fe}^{2+} \text {, } \\
10 \mathrm{~g} \mathrm{~L}^{-1} \mathrm{H}_{2} \mathrm{O}_{2}, \mathrm{pH} 3^{2}\end{array}$ & Uncontrolled & 8 & 35 & $4594 \mathrm{mg} \mathrm{COD} \mathrm{L}{ }^{-1}$ & This study \\
\hline
\end{tabular}


Table 3 Concentrations of VFAs under different pretreatment conditions when the maximal VFAs accumulation was achieved ${ }^{a}$

\begin{tabular}{|c|c|c|c|c|c|c|}
\hline & HAc & HPr & $\mathrm{i}-\mathrm{HBu}$ & $n$-HBu & i-HVa & $n$-HVa \\
\hline Control & $182 \pm 5$ & $237 \pm 27$ & $79 \pm 4$ & $55 \pm 6$ & $161 \pm 12$ & $36 \pm 4$ \\
\hline US & $1146 \pm 57$ & $824 \pm 18$ & $252 \pm 3$ & $501 \pm 25$ & $413 \pm 2$ & $350 \pm 9$ \\
\hline US/Fenton & $2039 \pm 32$ & $754 \pm 24$ & $348 \pm 9$ & $447 \pm 11$ & $524 \pm 2$ & $482 \pm 10$ \\
\hline
\end{tabular}

${ }^{a}$ The units of individual VFA is $\mathrm{mg}$ COD L ${ }^{-1}$. The values are means of two replicates $\pm \mathrm{SD}$.

(no. 4) also accelerated VFAs accumulation. ${ }^{29}$ Hydroxyl radicals produced by Fenton treatment could easily discharge intracellular organic substances into the liquid phase, which was beneficial for VFAs accumulation. ${ }^{15}$ Thus, the combined US/ Fenton pretreatment can be seen as an effective way to promote VFAs accumulation.

Short-chain fatty acids $\left(\mathrm{C}_{2}\right.$ to $\left.\mathrm{C}_{5}\right)$, which can be formed directly from the fermentation of carbohydrates, proteins and lipids, are usually the main products of the acidogenic digestion of sludge. ${ }^{23}$ The VFAs composition and percentage corresponding to the maximum VFAs yield are detailed in Table 3 and Fig. 5. HAc is the most suitable substrate for many bioprocesses such as biogas production and biopolymer production. ${ }^{29}$ As shown in Table 3, for all tested pretreatments, when the maximum VFAs yield was achieved, HAc had the highest concentration among all acids. The highest HAc concentration after US/Fenton treatment was $2039 \mathrm{mg}$ COD L ${ }^{-1}$, which was 1.72-fold and 1.78-fold those obtained in the Fenton and US tests, respectively. VFAs composition analysis (Fig. 5) revealed that HAc and HPr were the two main products, irrespective of the treatment. However, the VFAs composition was different among the pretreated tests and the control test. The order of VFAs abundance in the pretreated tests was HAc $>\mathrm{HPr}$, while it was HPr $>$ HAc in the control test. Therefore, the WAS pretreatment affected not only the types of particulates being hydrolyzed, but also the types of VFAs produced. This result was different from that of Yang et al., who detected that iso-HBu was the second major VFA component during the fermentation process. ${ }^{9}$ This difference may be caused by the different effects

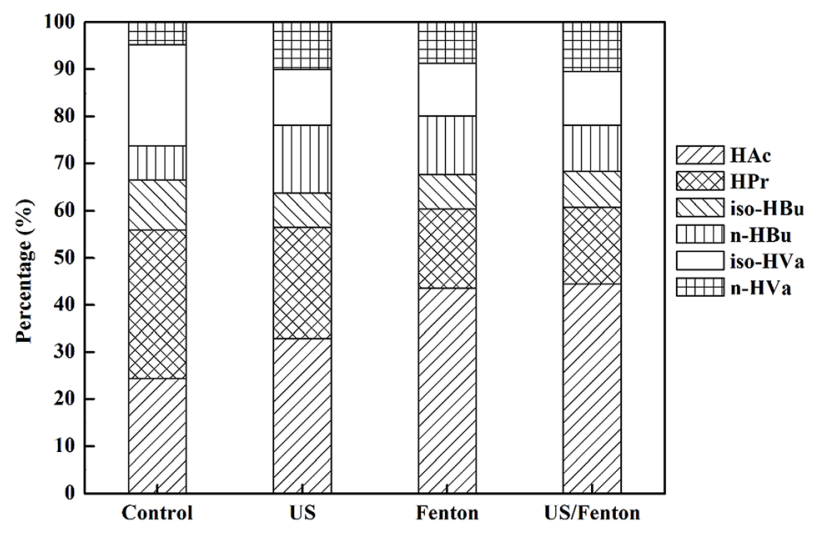

Fig. 5 Percentage of individual VFA of total VFAs concentration.

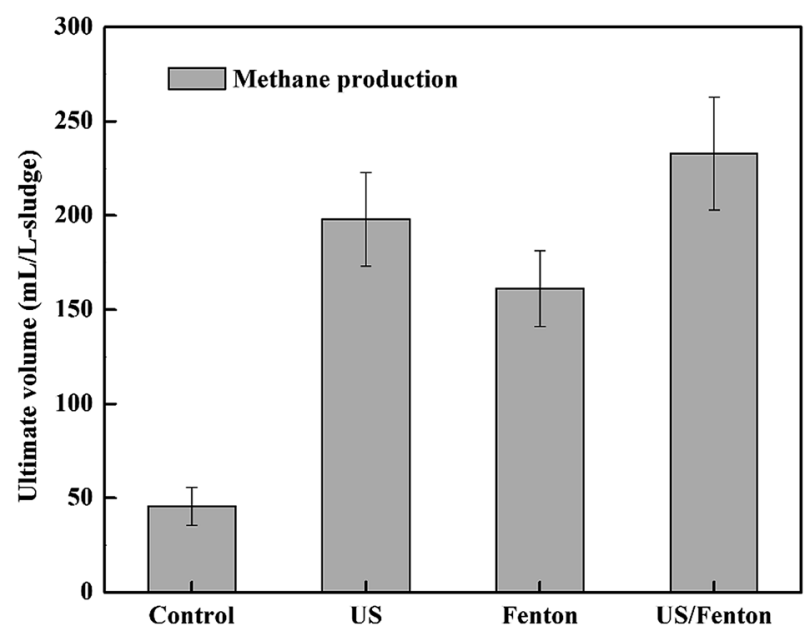

Fig. 6 Ultimate methane production during anaerobic fermentation.

of the different pretreatment methods on the microbial communities in WAS.

\subsection{Ultimate methane production}

During sludge fermentation, the effect of pretreatment on methanogen activity expressed by ultimate methane production is shown in Fig. 6. Compared with untreated sludge, ultimate methane production was enhanced by the US and Fenton pretreatment. Meanwhile, the US/Fenton treatment produced the highest ultimate methane yield $(232.80 \mathrm{~mL} / \mathrm{L}$-sludge $)$, which was 1.4-fold, 1.17-fold and 5.2-fold of those obtained in the Fenton, US and control tests, respectively. The small variation in methane production between the US and US/Fenton pretreatments may be due to redundant $\mathrm{H}_{2} \mathrm{O}_{2}$, which could decrease the rate of methane production as well as the ultimate methane production of WAS via advanced oxidation. ${ }^{30}$ Thus, a higher VFAs accumulation was observed using the US/Fenton pretreatment. Meanwhile, the higher VFAs concentration induced a lower $\mathrm{pH}$ value, which had a negative effect on methanogenic bacteria.

\section{Conclusions}

The effects of US, Fenton, and US/Fenton pretreatments on WAS hydrolysis and acidification were experimentally investigated in this study. The results showed that: 
(1) WAS organics could be effectively released from microbial intracellular environments into the extracellular environment by US/Fenton pretreatment.

(2) WAS acidification could also be enhanced by US/Fenton pretreatment.

(3) The ultimate methane production obtained in pretreated sludge was higher than that obtained in untreated sludge.

(4) The US/Fenton pretreatment had a synergetic effect on improving the hydrolysis and subsequent acidification process, making it more effective than individual US and Fenton treatments.

\section{Acknowledgements}

This work was supported by the National Natural Science Foundation (30470054); the Scientific and Technological Project of Liaoning Province (2001304024); the Natural Science Foundation of Liaoning Province (no. 20120132); Liaoning Province Science and the Cause of Public Research Fund (no. 20111012); the Bureau of Shenyang City Science and Technology Research Foundation (no. F12-277-1-39); and the City State Key Laboratory of Water Resources and Water Environment of open fund (no. HC201214).

\section{References}

1 L. Appels, J. Baeyens, J. Degreve and R. Dewil, Prog. Energy Combust. Sci., 2008, 34, 755-781.

2 X. Zhou, G. M. Jiang, Q. L. Wang and Z. G. Yuan, RSC Adv., 2014, 4, 50644-50652.

3 S. S. Yang, W. Q. Guo, Y. D. Chen, X. J. Zhou, H. S. Zheng, X. H. Feng, R. L. Yin and N. Q. Ren, RSC Adv., 2014, 4, 52892-52897.

4 A. Tiehm, K. Nickel, M. Zellhorn and U. Neis, Water Res., 2001, 35, 2003-2009.

5 W. S. Lee, A. S. M. Chua, H. K. Yeoh and G. C. Ngoh, Chem. Eng. J., 2014, 235, 83-99.

6 D. H. Kim, E. Jeong, S. E. Oh and H. S. Shin, Water Res., 2010, 44, 3093-3100.

7 A. J. Zhou, C. X. Yang, F. Y. Kong, D. D. Liu, Z. B. Chen, N. Q. Ren and A. J. Wang, J. Environ. Biol., 2013, 34, 381-389.

8 M. Tokumura, M. Sekine, M. Yoshinari, H. T. Znad and Y. Kawase, Process Biochem., 2007, 42, 627-633.

9 C. X. Yang, W. Z. Liu, Z. W. He, S. Thangavel, L. Wang, A. J. Zhou and A. J. Wang, Bioresour. Technol., 2014, 175, 509-516.
10 A. M. Yeneneh, S. Chong, T. K. Sen, H. M. Ang and A. Kayaalp, Water, Air, Soil Pollut., 2013, 224, 1559-1567.

11 S. Pilli, P. Bhunia, S. Yan, R. J. LeBlanc, R. D. Tyagi and R. Y. Surampalli, Ultrason. Sonochem., 2011, 18, 1-18.

12 F. Wang, Y. Wang and M. Ji, J. Hazard. Mater., 2005, 123, 145-150.

13 V. K. Tyagi, S. L. Lo, L. Appels and R. Dewil, Crit. Rev. Environ. Sci. Technol., 2014, 44, 1220-1288.

14 E. Neyens and J. Baeyens, J. Hazard. Mater., 2003, 98, 33-50. 15 J. L. de Morais and P. P. Zamora, J. Hazard. Mater., 2005, 123, 181-186.

16 S. Qiu, M. J. Xia and Z. S. Li, Water Sci. Technol., 2013, 67, 1701-1707.

17 X. A. Ning, H. Chen, J. R. Wu, Y. J. Wang, J. Y. Liu and M. Q. Lin, Chem. Eng. J., 2014, 242, 102-108.

18 APHA, The Standard Methods for the Examination of Water and Wastewater, American Public Health Association, Washington, DC, USA, 21st edn, 2005.

19 D. Herbert, P. J. Phipps and R. E. Strange, in Methods in Microbiology, ed. J. R. Norris and D. W. Ribbons, Academic Press, 1971, part B, pp. 209-344.

20 P. K. Smith, R. I. Krohn, G. T. Hermanson, A. K. Mallia, F. H. Gartner, M. D. Provenzano, E. K. Fujimoto, N. M. Goeke, B. J. Olson and D. C. Klenk, Anal. Biochem., 1985, 150, 76-85.

21 A. J. Zhou, J. W. Du, C. Varrone, Y. Z. Wang, A. J. Wang and W. Z. Liu, Process Biochem., 2014, 49, 283-289.

22 T. T. H. Pham, S. K. Brar, R. D. Tyagi and R. Y. Surampalli, Ultrason. Sonochem., 2010, 17, 38-45.

23 Y. G. Chen, S. Jiang, H. Y. Yuan, Q. Zhou and G. W. Gu, Water Res., 2007, 41, 683-689.

24 Y. Miron, G. Zeeman, J. B. Van Lier and G. Lettinga, Water Res., 2000, 34, 1705-1713.

25 Z. Y. Ji, G. L. Chen and Y. G. Chen, Bioresour. Technol., 2010, 101, 3457-3462.

26 Y. Y. Yan, L. Y. Feng, C. J. Zhang, C. Wisniewski and Q. Zhou, Water Res., 2010, 44, 3329-3336.

27 X. L. Liu, H. Liu, J. H. Chen, G. C. Du and J. Chen, Waste Manage., 2008, 28, 2614-2622.

28 X. R. Kang, G. M. Zhang, L. Chen, W. Y. Dong and W. D. Tian, Ind. Eng. Chem. Res., 2011, 50, 12372-12378.

29 C. X. Yang, A. J. Zhou, Z. W. He, L. Jiang, Z. C. Guo, A. J. Wang and W. Z. Liu, Environ. Sci. Pollut. Res., 2015, 1-10.

30 C. Eskicioglu, A. Prorot, J. Marin, R. L. Droste and K. J. Kennedy, Water Res., 2008, 42, 4674-4682. 